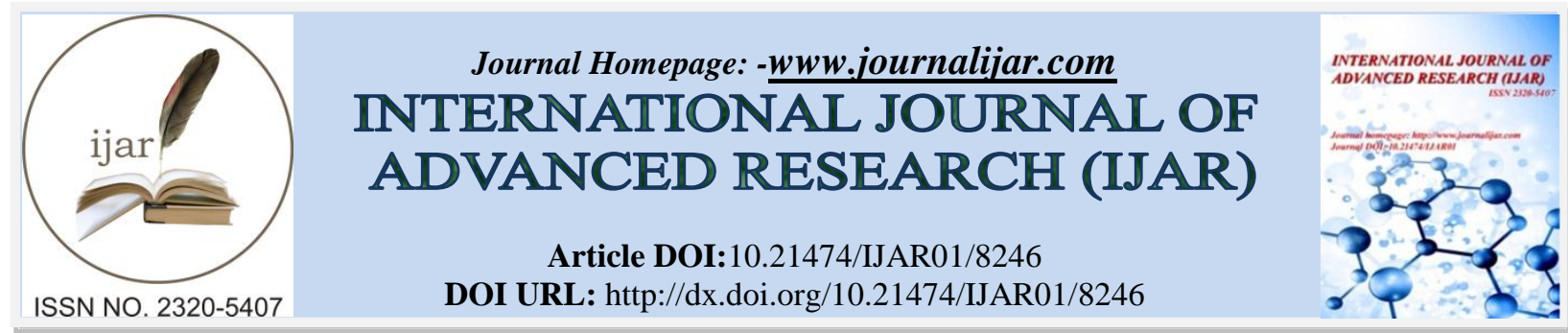

RESEARCH ARTICLE

\title{
ROLE OF NANO PHOSPHORUS IN MAIZE AND PIGEONPEA BASED INTERCROPPING SYSTEM UNDER MEDIUM-UPLAND SITUATION OF JHARKHAND.
}

\section{Deban kumar choudhary ${ }^{1}$, Birendra Kumar ${ }^{1}$ and Chandan Bharti ${ }^{2}$.}

1. Department of Agronomy, Faculty of Agriculture.

2. Department of Plant pathology, BCKV, Mohanpur, WB- 741252.

\section{Manuscript Info}

\section{Manuscript History}

Received: 20 October 2018

Final Accepted: 22 November 2018

Published: December 2018

\section{Key words:-}

Black gram, Pigeon-pea, Maize, Harvest index, Nano- $\mathrm{P}$ and system productivity.

\section{Abstract}

All India Coordinated Research Project on Pulses Research of Birsa Agricultural University, Ranchi (Jharkhand) was conducted an experiment for two consecutive years during Kharif 2016 and 2017 with a view to study the response of Phosphorus on maize and Pigeon pea based inter-cropping system.

Maximum grain yield of pigeon pea and black gram were recorded with $50 \%$ RDP+ Nano-P 40 ppm followed by $100 \%$ RDP and Nano-P 40 $\mathrm{ppm}$. Application of Nano-P $40 \mathrm{ppm}$ increased grain yield of pigeon pea, maize and black gram compared to no phosphorus.

Pigeon pea + black gram 1:1 recorded higher straw yield of pigeon pea than that of pigeon pea + black gram 1:2 system and sole pigeon pea. Likewise, straw yield of maize under maize + black gram1:1 was found higher than that of sole maize and maize + black gram 1:2 system. Straw yield of black gram was registered higher in both plant geometry with pigeon pea $(1: 1$ and1:2) than that of similar combinations with maize. Concerning to phosphorus management maximum straw yield of pigeon pea, black gram and maize were recorded with 50\% RDP+ Nano-P $40 \mathrm{ppm}$ followed by 100\% RDP and Nano-P $40 \mathrm{ppm}$. Minimum grain and straw yield was registered under no phosphorus application.

System productivity in terms of Black gram equivalent yield $(1763 \mathrm{~kg}$ $\mathrm{ha}^{-1}$ ) was recorded under pigeon pea + black gram 1:1 system which is statistically at par with pigeon pea + black gram 1:2 followed by maize + black gram 1:2 and maize + black gram 1:1. All the crop combination gave higher black gram equivalent yield and was found superior over sole crop of black gram, pigeon pea and maize. The lowest black gram equivalent yield was obtained with sole maize $\left(884 \mathrm{~kg} \mathrm{ha}^{-1}\right)$. System productivity of pigeon pea + black gram 1:1 and pigeon pea + black gram 1:2 increased by $58.8 \%$ and $52.8 \%$ respectively over sole pigeon pea.

Copy Right, IJAR, 2017,. All rights reserved.
Corresponding Author:-Deban kumar choudhary.

Address:-Department of Agronomy, Faculty of Agriculture. 


\section{Introduction:-}

Jharkhand a newly created state having nearly 40 per cent of cultivable land under medium to upland land situation with medium to poor soil health. As Jharkhand has good rain fall and we are experiencing nearly 1300 to $1400 \mathrm{~mm}$ rain fall. Due to topography and rapid occurrence of rain farmers faces situation like partial dry. During Kharif low land preferably be covered by rice, while medium to upland can be successfully utilized by crops like less water requirement with high energy value, which not only nourished human being but also enrich soil health. To diversify the area under upland rice, a suitable short duration crop/intercropping system is required to increase the productivity in upland. Thus, in order to meet the food, feed, fiber, nutritional and other requirements of the increasing human population, productivity of cereals and pulses particularly in upland ecosystem of India as well as Jharkhand has to be enhanced.

Black gram is one of the important pulse crops in India and occupies an area of 4.49 million hectare with an average productivity of $652 \mathrm{~kg} \mathrm{ha}^{-1}$. In Jharkhand, it occupies an area of 94.9 thousand hectare with a production of 0.14 million tonne, and productivity of $933 \mathrm{~kg} \mathrm{ha}^{-1}$ (DoA. Govt. of Jharkhand, 2017-18). It is a very good source of protein $(22.3 \%)$, calcium $(154 \mathrm{mg})$, iron $(9.1 \mathrm{mg})$, fat $(1.4 \mathrm{~g})$, riboflavin $(0.37 \mathrm{~g})$ and thiamin $(0.42 \mathrm{mg})$ per $100 \mathrm{~g}$ (Asaduzzaman et al., 2010). The crop has special importance in intensive cropping system of the country due to its short maturity period and weeds being less competitive against it during early crop growth stage. Intercrop of black gram with pigeon pea or maize can be a suitable option for rainfed upland condition, as this region largely depends upon vagaries of monsoon. Intercropping of legumes with cereals offers scope for developing energy efficient and sustainable agriculture. Efficiency of production in cereal-legume intercropping systems could be improved by minimizing inter-specific competition between the component crops for growth limiting factors.

In spite of liberal application of chemical fertilizers, a declining or stagnating yield trend has been observed in recent years which might be attributed to imbalanced supply of nutrients resulting in multiple nutrient deficiencies. Phosphorus is an important limiting primary nutrient element after nitrogen for plant growth and development. Besides, Phosphorus being the major nutrient plays a vital role in energy transformation, uniform grain filling, grain quality and higher yield. However, in acid lateritic soil of Jharkhand witnesses the major problem of applied $\mathrm{P}$ fixation and thereby causes low nutrients use efficiency and low yield of crops. This condition demands a smart nutrient delivery system so that crop can be supplied with proper and balanced amount of plant nutrients particularly $\mathrm{P}$-in acidic soil for maximum yield realization. In the recent past, application of Nano-P fertilizer has given a new dimension to crop production (Tarafdar et al. 2012). Alternatively, use of Nano-P in different combinations with bulk P-fertilizer for enhancing its use efficiency may be explored for profitable farming. The role of Nano phosphorus is to solve the problem of phosphorus fixation and supply adequate phosphorus to the crop for its proper growth and development. Use of Nano-P in legume based intercropping system is yet to be explored for cost effective option of P-management in acidic soils of Jharkhand

\section{Materials and Methods:-}

Field experiment was conducted at BAU, Ranchi, during kharif seasons of two consecutive years, 2016 and 2017. The soil condition of experimental plot were as mentioned here as physical character, Sand (60.8\%), Silt (27.8\%), Clay (11.4\%), Textural class (Sandy loam), Water holding capacity at saturation (37.6\%), Bulk density (1.58 M $\left.\mathrm{gcc}^{-1}\right)$, While chemical properties Organic carbon $\left(4.20 \mathrm{~g} \mathrm{~kg}^{-1}\right)$, Available $\mathrm{N}\left(191.7 \mathrm{~kg} \mathrm{ha}^{-1}\right)$, Available $\mathrm{P}(23.21 \mathrm{~kg}$ $\left.\mathrm{ha}^{-1}\right)$, Total P $\left(511.4 \mathrm{~kg} \mathrm{ha}^{-1}\right)$, Available $\mathrm{K}\left(157.8 \mathrm{~kg} \mathrm{ha}^{-1}\right), \mathrm{pH}$ (at $1: 2.5$ soil to water 5.40) and EC $\left(\mathrm{d} \mathrm{S} \mathrm{m}^{-1}\right.$ at $25^{\circ} \mathrm{C}$ 0.06). The experiment was laid out in split-plot Design with three replications. The treatments consisted of seven different crop geometry, i.e crop combination viz. C1 - sole black gram, C2 - sole pigeon pea, C3 - sole maize, C4 pigeon pea + black gram $(1: 1)$.

C5 -maize + black gram (1:1), C6 - pigeon pea + black gram (1:2) and C7 -maize + black gram (1:2) in main plots and four phosphorus management practices viz. P1- Control, P2- 40 ppm Nano-P, P3- 50\% recommended dose of phosphorus (RDP) +40 ppm Nano- P and P4-100 \% RDP in subplots. Pigeon pea var. UPAS-120, black gram var. Uttara and maize var. Suwan composite-1 were grown with 20:40:20:20, 20:40:20:20 and 120:60:40 kg/ ha N, $\mathrm{P}_{2} \mathrm{O}_{5}$, $\mathrm{K}_{2} \mathrm{O}$, and $\mathrm{S}$ respectively. Data on grain yield, seed yield were taken and yield equivalent as well as harvest index were calculated and further, using the standard established mathematical formula under mentioned parameter year wise was taken accordingly elaborated here. 


\section{Grain yield $\left(\mathrm{kg} \mathrm{ha}^{-1}\right)$ :-}

The dried grains of black gram, pigeon pea and maize from the net plot area were cleaned after threshing and weighed to compute the grain yield and expressed as $\mathrm{kg} \mathrm{ha}^{-1}$.

Stalk yield $\left(\mathrm{kg} \mathrm{ha}^{-1}\right.$.):-

Total biomass from each net plot was dried on sun. Before threshing, the bundle weight of each crop ( $\mathrm{kg} \mathrm{plot}^{-1}$ ) was taken. Stover yield was obtained by deducting the grain yield from the bundle weight and expressed in $\mathrm{kg} \mathrm{ha}^{-1}$.

\section{Harvest index:-}

Harvest index is the ratio of economic yield to biological yield of the crop. It was calculated by using following formula given by Donald (1962).

Harvest index $(\%)=\frac{\text { Economic yield }}{\text { Biological yield }} \times 100$

System productivity;-

System productivity was calculated in terms of black gram equivalent yield (BEY) by taking minimum support price of black gram, pigeon pea and maize issued by $\quad$ Government of India for the 2017-18.

\section{Result and Discussion:- \\ Grain yield (kg ha $\left.{ }^{-1}\right)$;-}

Data (Table 1) revealed that higher grain yield of pigeon pea was recorded under pigeon pea + black gram 1:1 than that of sole pigeon pea and pigeon pea + black gram 1:2 systems. Similarly, grain yield of maize registered maximum under maize + black gram 1:1 followed by sole maize and maize + black gram 1:2 systems. In the intercropping system, black gram produced higher grain yield under pigeon pea + black gram combinations $\left(\mathrm{C}_{4}\right.$ and $\left.\mathrm{C}_{6}\right)$ compared to maize + black gram combinations $\left(\mathrm{C}_{5}\right.$ and $\left.\mathrm{C}_{7}\right)$.

With respect to phosphorus management practices, maximum grain yield of pigeon pea and black gram were recorded with $50 \%$ RDP+ Nano-P 40 ppm followed by 100\% RDP and Nano-P 40 ppm while in case of maize, maximum grain yield. Application of Nano-P $40 \mathrm{ppm}$ increased grain yield of pigeon pea, maize and black gram compared to no phosphorus while minimum grain yield was registered under no phosphorus application. Although data was not analyzed but interaction between $\mathrm{C}_{4} \times \mathrm{P}_{3}$ recorded maximum grain yield. This might helped for efficient use for natural resources by the pigeon pea and black gram under intercropping system. The increase in grain yield in intercropping systems may be attributed to the application of SSP/bulk P fertilizers along with Nano phosphorus which possibly increased the $\mathrm{P}$ content in addition to $\mathrm{N}$, and $\mathrm{K}$ in soil solution and ultimately affected the formation of more nodules, vigorous root development, better $\mathrm{N}$ fixation and better development of plant growth leading to higher photosynthetic activity and translocation of photosynthetic to the sink which in turn resulted in better development of yield attributes and finally in higher grain yield. Under favorable environment, Nano-P + phosphatic fertilizers might have helped to maintain proper nutrient concentration in plant thereby boost in development of new shoot and ultimately increased the growth; yield attributes and finally yield of the crops. Similar results have been obtained by Patil and Padmani (2007), Pal et al. (2016) and Sahay et al. (2016).

Straw yield $\left(\mathrm{kg} \mathrm{ha}^{-1}\right)$ :-

Pigeon pea + black gram 1:1 recorded higher straw yield of pigeon pea than that of pigeon pea + black gram 1:2 system and sole pigeon pea. Likewise, straw yield of maize under maize + black gram1:1 was found higher than that of sole maize and maize + black gram 1:2 system. Straw yield of black gram was registered higher in both plant geometry with pigeon pea (1:1 and 1:2) than that of similar combinations with maize. Concerning to phosphorus management maximum straw yield of pigeon pea, black gram and maize were recorded with 50\% RDP+ Nano-P 40 ppm followed by $100 \%$ RDP and Nano-P 40 ppm. Minimum straw yield was registered under no phosphorus application (Table 2).

\section{Harvest index (\%):-}

Maximum harvest index of pigeon pea was recorded under $\left(\mathrm{C}_{4}\right)$ followed by $\left(\mathrm{C}_{2}\right)$ and $\left(\mathrm{C}_{6}\right)($ Table 3$)$. Higher harvest index of maize was noted under $C_{5}$ plant geometry compared to $C_{7}$ and $C_{3}$. Harvest index of black gram was higher in pigeon pea + black gram system (1:1or1:2) compared to maize + black gram systems (1:1or 1:2).. With regards to phosphorus management practices, maximum harvest index of pigeon pea and black gram were recorded with 50\% 
RDP+ Nano-P 40 ppm followed by $100 \%$ RDP and Nano-P 40 ppm while in case of maize, higher harvest index was registered under $100 \%$ RDP followed by $50 \%$ RDP+ Nano-P 40 ppm and Nano-P 40 ppm. Minimum harvest index in all plant geometry were reported under no phosphorus application (Table 3). Grain and straw yield of pigeon pea, maize and black gram increased as results of increasing levels of phosphorus up to $100 \%$ RDP. However, maximum increase in yield was reported when $50 \%$ of phosphotic fertilizer with Nano-P40 ppm applied plots. Mardalipour et al. (2014) observed that Nano bio-fertilizer application in wheat increased spike length, spike number, seed number, seed number in spike, seed weight and number of days until maturity. Generally, Nano biofertilizer application increased crop growth and improved yield and yield components through extending growing period. Tarafdar et al. (2012) reported that under arid condition (40 ppm concentration) foliar application of Nanophosphorus gave $80 \mathrm{~kg} \mathrm{ha}^{-1} \mathrm{P}$ of cluster bean and pearl millet. The improvement in yield components might have resulted from favorable influence of phosphorus nutrition on the growth parameters (plant height, LAI, branching and dry matter accumulation) finally leading to greater nutrient uptake, efficient partitioning of metabolites, adequate translocation and accumulation of photosynthesis (Tisdale et al., 1995).

Such observations were also recorded by Yadav et al. (1992), Singh et al. (1998), Shivran et al. (2000) and Adhikari et al. (2014). The increase in grain, as well as biological yield and harvest index of pigeon pea due to application of Nano-P and phosphatic fertilizer was largely a function of improved growth, translocation of more photosynthates from source to sink and consequent development of yield attributes. These results are in conformity with the results of Chittapur et al. (1994) and Jat and Ahlawat (2003). Application of phosphorus also enhanced the yield attributes viz., pods plant ${ }^{-1}$, grains pod $^{-1}$ and grain, and Stover yields of black gram.

System productivity /Black gram equivalent yield $\left(\mathrm{kg} \mathrm{ha}^{-1}\right)$ :-

Data on system productivity i.e. Black gram equivalent yield (Table 4) as influenced by cropping system and phosphorus management sown in Table 6 reflect that, black gram equivalent yield $\left(1763 \mathrm{~kg} \mathrm{ha}^{-1}\right)$ was recorded under pigeon pea + black gram 1:1 system which is statistically at par with pigeon pea +black gram 1:2 followed by maize + black gram 1:2 and maize + black gram 1:1. All the crop combination gave higher black gram equivalent yield and was found superior over sole crop of black gram, pigeon pea and maize. The lowest black gram equivalent yield was obtained with sole maize $\left(884 \mathrm{~kg} \mathrm{ha}^{-1}\right)$. However, cropping system $\mathrm{C}_{4}$ and $\mathrm{C}_{6}$ recorded significantly superior system productivity over $\mathrm{C}_{5}$ and $\mathrm{C}_{7}$ treatments. With regards to phosphorus management practices, it markedly influenced the black gram equivalent yield as evident from data. Maximum black gram equivalent yield $\left(1438 \mathrm{~kg} \mathrm{ha}^{-1}\right)$ was registered under 50\% RDP + Nano-P $40 \mathrm{ppm}\left(\mathrm{P}_{3}\right)$ which was at par with $100 \%$ RDP $\left(\mathrm{P}_{4}\right)$ followed by Nano-P $40 \mathrm{ppm}\left(\mathrm{P}_{2}\right)$. The application of no phosphorus $\left(\mathrm{P}_{1}\right)$ recorded lowest system productivity $\left(1111 \mathrm{~kg} \mathrm{ha}^{-1}\right)$.

Interaction effect between crop combination and phosphorous management was significant. System productivity of pigeon pea + black gram 1:1( $\left.\mathrm{C}_{4}\right)$ or pigeon pea + black gram 1:2 systems $\left(\mathrm{C}_{6}\right)$ with application of Nano-P $40 \mathrm{ppm}$ $\left(\mathrm{P}_{2}\right)$ in similar crop combination were found superior to no phosphorus application $\left(\mathrm{P}_{1}\right)$ whereas, maize + black gram 1:1 $\left(\mathrm{C}_{5}\right)$ or maize + black gram 1:2 $\left(\mathrm{C}_{7}\right)$ with application of Nano-P $40 \mathrm{ppm}\left(\mathrm{P}_{2}\right)$ remained at par with no phosphorus application (P1) in similar crop combination. However, maximum system productivity was recorded under pigeon pea + black gram 1:1 $\left(\mathrm{C}_{4}\right)$ X 50\% RDP+ 40 ppm Nano-P $\left(\mathrm{P}_{3}\right)$ which remained at par with $\mathrm{C}_{6} \mathrm{x}_{3}, \mathrm{C}_{4} \times \mathrm{P}_{4}$ and $\mathrm{C}_{6} \mathrm{X}$ $\mathrm{P}_{4}$ but superior to the rest of the combinations.

The BEY of interaction table indicated that pigeon pea + black gram 1:1 was found maximum at all the phosphorus levels i.e. $\mathrm{P}_{2}, \mathrm{P}_{3}$ and $\mathrm{P}_{4}$ which was at par with pigeon pea + black gram 1:2. Maximum BEY (1977) was recorded with the treatment combination of pigeon pea +black gram 1:1 with50\% RDP +Nano- P 40ppm $\left(\mathrm{P}_{3}\right)$. It was observed that at different levels of $\mathrm{P}$ in pigeon pea + black gram 1:1 the BEY increase significantly up to $\mathrm{P}_{3}$ after that i.e. at $\mathrm{P}_{4}$ the BEY reduced significantly. In maize + black gram 1:1 $\left(\mathrm{C}_{5}\right)$ and maize + black gram 1:2 $\left(\mathrm{C}_{7}\right)$ the BEY was increase significantly up to $\mathrm{P} 3$ but at $\mathrm{P}_{4}$ the increase was not significant. In case of $\mathrm{C}_{7}$ (maize + black gram 1:2) again BEY increased significantly up to $\mathrm{P}_{3}$.

\begin{tabular}{|l|c|c|c|c|c|c|c|c|c|c|}
\hline \multirow{2}{*}{$\begin{array}{l}\mathbf{T} \\
\mathbf{r}\end{array}$} & \multicolumn{2}{|c|}{$\mathbf{P}_{\mathbf{1}^{-}}$} & \multicolumn{2}{|c|}{$\mathbf{P}_{\mathbf{2}^{-}}$} & \multicolumn{2}{|c|}{$\mathbf{P}_{\mathbf{3}^{-5}} \mathbf{5 0}$} & \multicolumn{2}{c|}{$\mathbf{P}_{\mathbf{4}^{-}}$} & \multicolumn{2}{c|}{ Mean } \\
\cline { 2 - 11 } & $\mathbf{B}$ & $\mathbf{P}$ & $\mathbf{B}$ & $\mathbf{P}$ & $\mathbf{B}$ & $\mathbf{P}$ & $\mathbf{B}$ & $\mathbf{P}$ & $\mathbf{B}$ & $\mathbf{P}$ \\
\hline $\mathbf{C}$ & 8 & & 8 & & 1 & & 1 & & 1 & 1 \\
\hline $\mathrm{C}$ & & 9 & & 1 & & 1 & & 1 & & 1 \\
\hline
\end{tabular}




\begin{tabular}{|l|l|l|l|l|l|l|l|l|l|l|}
\hline $\mathrm{C}$ & & 3 & & 3 & & 3 & & 3 & 3 \\
\hline $\mathrm{C}$ & 4 & ( & 5 & ( & 6 & ( & 6 & ( & 5 & ( \\
\hline $\mathrm{C}$ & 3 & ( & 2 & ( & 3 & ( & 4 & ( & 3 & ( \\
\hline $\mathrm{C}$ & 5 & ( & 6 & ( & 8 & ( & 7 & ( & 6 & ( \\
\hline $\mathrm{C}$ & 4 & ( & 5 & ( & 6 & ( & 5 & ( & 5 & ( \\
\hline $\mathrm{M}$ & 5 & 9 & 5 & 1 & 7 & 1 & 7 & 1 & \\
\hline
\end{tabular}

Table 1:-Grain yield $\left(\mathrm{kgha}^{-1}\right)$ as influenced by legume based crop geometry and phosphorus management(mean of 2016 and 2017).

BG-black gram, PP- pigeon pea, M-maize,NB: Value in parenthesis is of pigeon pea (C4\&C6) and maize (C5\&C7)

Table 2:-Straw yield $\left(\mathrm{kg} \mathrm{ha}^{-1}\right)$ as influenced by legume based crop geometry and phosphorus management(mean of 2016 and 2017).

\begin{tabular}{|c|c|c|c|c|c|c|c|c|c|c|}
\hline \multirow{2}{*}{$\begin{array}{l}\mathbf{T} \\
\mathbf{r}\end{array}$} & \multicolumn{2}{|c|}{$\mathbf{P}_{1^{-}}$} & \multicolumn{2}{|c|}{$\mathbf{P}_{2^{-}}$} & \multicolumn{2}{|c|}{$P_{3^{-50}}$} & \multicolumn{2}{|c|}{$\mathbf{P}_{4^{-}}$} & \multicolumn{2}{|c|}{ Mea } \\
\hline & B & $\mathbf{P}$ & B & $\mathbf{P}$ & B & $\mathbf{P}$ & B & $\mathbf{P}$ & B & $\mathbf{P}$ \\
\hline $\mathrm{C}$ & 2 & & 3 & & 3 & & 3 & & 3 & \\
\hline $\mathrm{C}$ & & 4 & & 4 & & 5 & & 5 & & 5 \\
\hline $\mathrm{C}$ & & 7 & & 7 & & 8 & & 7 & & 7 \\
\hline $\mathrm{C}$ & 1 & ( & 1 & ( & 2 & ( & 2 & ( & 1 & ( \\
\hline $\mathrm{C}$ & 1 & ( & 1 & ( & 1 & ( & 1 & ( & 1 & ( \\
\hline $\mathrm{C}$ & 1 & ( & 2 & ( & 2 & ( & 2 & ( & 2 & ( \\
\hline $\mathrm{C}$ & 1 & ( & 1 & ( & 2 & ( & 2 & ( & 1 & ( \\
\hline $\mathrm{M}$ & 1 & ( & 1 & ( & 2 & ( & 2 & ( & & \\
\hline
\end{tabular}

BG-black gram, PP- pigeon pea, M-maize,NB: Value in parenthesis is of pigeon pea (C4\&C6) and maize (C5\&C7)

Table 3:-Harvest index $(\%)$ as influenced by legume based crop geometry and phosphorus management (pooled of 2016 and 2017).

\begin{tabular}{|c|c|c|c|c|c|c|c|c|c|c|}
\hline \multirow{2}{*}{$\begin{array}{l}\mathbf{T} \\
\mathbf{r}\end{array}$} & \multicolumn{2}{|c|}{$P_{1-}$} & \multicolumn{2}{|c|}{$\mathbf{P}_{2^{-}}$} & \multicolumn{2}{|c|}{$P_{3}-50$} & \multicolumn{2}{|c|}{$\mathbf{P}_{4-}$} & \multicolumn{2}{|c|}{ Mea } \\
\hline & B & $\mathbf{P}$ & B & $\mathbf{P}$ & B & $\mathbf{P}$ & B & $\mathbf{P}$ & B & $\mathbf{P}$ \\
\hline $\mathrm{C}$ & 2 & & 2 & & 2 & & 2 & & 2 & \\
\hline $\mathrm{C}$ & & 1 & & 1 & & 1 & & 1 & & 1 \\
\hline $\mathrm{C}$ & & 2 & & 2 & & 3 & & 3 & & 2 \\
\hline $\mathrm{C}$ & 2 & ( & 2 & ( & 2 & ( & 2 & ( & 2 & ( \\
\hline $\mathrm{C}$ & 2 & ( & 2 & ( & 2 & ( & 2 & ( & 2 & ( \\
\hline $\mathrm{C}$ & 2 & ( & 2 & ( & 2 & ( & 2 & ( & 2 & ( \\
\hline $\mathrm{C}$ & 2 & ( & 2 & ( & 2 & ( & 2 & ( & 2 & ( \\
\hline \multirow[t]{2}{*}{$\mathrm{M}$} & 2 & 1 & 2 & 1 & 2 & 1 & 2 & 1 & & \\
\hline & & & & & \multicolumn{2}{|c|}{ S. Em } & \multicolumn{2}{|c|}{ CD at } & \multicolumn{2}{|c|}{ CV } \\
\hline \multicolumn{5}{|c|}{ Crop combination (only black gram) } & \multicolumn{2}{|c|}{0.41} & \multicolumn{2}{|c|}{1.32} & \multirow{4}{*}{\multicolumn{2}{|c|}{7.5}} \\
\hline \multicolumn{5}{|c|}{ Phosphorus management } & \multicolumn{2}{|c|}{0.24} & \multicolumn{2}{|c|}{0.71} & & \\
\hline \multirow{2}{*}{$\begin{array}{l}\text { Int } \\
\text { era }\end{array}$} & & \multicolumn{3}{|c|}{ Between $\mathrm{P}$, at same } & & & \multicolumn{2}{|c|}{ NS } & & \\
\hline & & \multicolumn{3}{|c|}{ Between $\mathrm{C}$, at same or } & & & \multicolumn{2}{|c|}{$\mathrm{NS}$} & & \\
\hline
\end{tabular}

BG-black gram, PP- pigeon pea, M-maize,NB: Value in parenthesis is of pigeon pea (C4\&C6) and maize (C5\&C7)

Table 4:-Black gram equivalent yield, BEY $\left(\mathrm{kgha}^{-1}\right)$ as influenced by legume based crop geometry and phosphorus management (pooled of 2016 and 2017).

\begin{tabular}{|l|c|c|c|c|c|}
\hline Treatme & $\mathbf{P}_{\mathbf{1}^{-}}$ & $\mathbf{P}_{\mathbf{2}^{-}}$ & $\mathbf{P}_{\mathbf{3}^{-}}$ & $\mathbf{P}_{\mathbf{4}^{-}}$ & $\mathbf{M e}^{-}$ \\
\hline $\mathrm{C}_{1^{-}}$Sole & 818 & 889 & 117 & 113 & 100 \\
\hline $\mathrm{C}_{2}$-Sole & 994 & 104 & 122 & 120 & 111 \\
\hline
\end{tabular}




\begin{tabular}{|c|c|c|c|c|c|}
\hline $\mathrm{C}_{3}$-Sole & 799 & 840 & 940 & 956 & 884 \\
\hline $\mathrm{C}_{4^{-}}$ & 1504 & 166 & 197 & 190 & 176 \\
\hline $\mathrm{C}_{5^{-}}$ & 1088 & 115 & 136 & 138 & 124 \\
\hline $\mathrm{C}_{6^{-}}$ & 1414 & 160 & 193 & 188 & 170 \\
\hline $\mathrm{C}_{7^{-}}$ & 1161 & 124 & 145 & 143 & 132 \\
\hline Mean & 1111 & 120 & 143 & 141 & \\
\hline & & & S. & CD & $\mathbf{C V}$ \\
\hline \multicolumn{3}{|c|}{ Crop combination } & 21.6 & 66.7 & \multirow[t]{4}{*}{8.2} \\
\hline \multicolumn{3}{|c|}{ Phosphorus management } & 11.8 & 33.6 & \\
\hline \multirow{2}{*}{$\begin{array}{c}\text { Interactio } \\
n\end{array}$} & \multicolumn{2}{|c|}{ Between $\mathrm{P}$, at same } & 43.3 & 91.9 & \\
\hline & \multicolumn{2}{|c|}{ Between $\mathrm{C}$, at same or } & 34.6 & 101. & \\
\hline
\end{tabular}

BG-black gram, PP- pigeon pea, M-maize

System productivity of pigeon pea + black gram 1:1 and pigeon pea + black gram 1:2 increased by $58.8 \%$ and $52.8 \%$ respectively over sole pigeon pea. The productivity of intercropping system is not only governed by the inputs applied to the crops but also by the harmony between the crops grown in association and inclusion of legumes in these systems helps in utilizing natural resources efficiently and maintaining the fertility status of soil which may contributes to the productivity of the component crop.

Combined application of inorganic phosphorus and Nano-P, also helped in conversion of unavailable nutrients to available form through increased enzymatic and microbial activity and enabled the crop to absorb nutrients resulting in higher dry matter production. Besides, nutrients management through inorganic phosphorus and Nano- phosphorus application improved the physical, chemical and biological properties of the soil, which provided congenial conditions for the pigeon pea and black gram. These results are in accordance with the findings of Ali et al. (2003) and Nagar et al. (2015).

Summery and conclusion:-

Pigeon pea grown at row to row distance of $60 \mathrm{~cm}$ and one row of Black gram in between rows of Pigeon pea produced better growth, grain yield, straw yield as well as system productivity in terms of black gram equivalent yield. The grain yield and straw yield of the system productivity at $50 \% \mathrm{RDP}+40 \mathrm{ppm}$ nano $\mathrm{P}$ which were comparable under same intercropping system at 100 per cent recommended dose of Phosphorus. Pigeon pea and black gram (1:1) ratio with 50\% RDP+ Nano-P 40 ppm produced higher grain yield, straw yield as well as $58.8 \%$ more system productivity over sole pigeon pea

\section{Acknowledgment:-}

We are very thankful to department Agronomy and our chairman for his kind cooperation and his help during preparation of this report.

\section{Refrences:-}

1. Adhikari, T., Kundu, S., Meena., V. and Rao, A.S. 2014. Utilization of Nano rock phosphate by maize crop in a Vertisol of central India.Journal of Agricultural Science and Technology, 4: 384-394.

2. Anonymous, Annual Report2017.Directorate of Agriculture, Jharkhand.

3. Asaduzzaman, M., Sultana, S., Roy, T.S. and Masum, S.M. 2010. Weeding and plant spacing effects on the growth and yield of black gram.Bangladesh Res. Publication Journal, 4(1): 62-68. www.bdresearchpublication.com/ admin/journal/upload/09155/ 09155.pdf

4. Chittapur, B.M., Kulkarni, B.S., Hiremath, S.M. and Hosmani, M.M. 1994. Influence of nitrogen and phosphorus on growth and yield of short duration pigeonpea. Indian Journal of Agronomy, 39(4):657-659.

5. Jat, H.S. and Ahlawat, I.P.S. 2004. Production potential and economic viability of pigeonpea (Cajanuscajan) + groundnut (Arachishypogaea) intercropping in Indo-Gangetic plains. Indian Journal of Agricultural Sciences, 74(3): 126-129.

6. Mardalipour, M., Zahedi, H. and Sharghi, Y. 2014.Evaluation of Nano bio-fertilizer efficiency on agronomic traits of spring wheat at different sowing date.Biological Forum-An International Journal, 6(2): 349-356. 
7. Nagar, R.K., Goud, V.V., Kumar, R. and Kumar, R. 2015. Effect of incorporation of FYM, pigeonpea stalk, phosphocompost on growth, yield and nutrient uptake in pigeonpea based intercropping system. The Bioscan: An International Quarterly Journal of Life Sciences,10(3): 339-343.

8. Pal, A.K., Singh, R.S., Shukla, U.N.and Singh, S. 2016. Growth and production potential of pigeonpea [Cajanuscajan (L.) Millsp.]as influenced by intercropping and integrated nutrient management. Journal of Applied and Natural Science,8(1): 179 -183.

9. Patil, A.B. and Padmani, D.R. 2007. Nutrient uptake pattern of pigeonpea (Cajanuscajan) as influenced by integrated nutrient management. International Journal of Agricultural Sciences,3(2): 176-178.

10. Sahay, A., Pratap, T., Tyagi, S., Nanher, A.H., Singh, R., Singh, S.S. and Singh, V.D. 2016. Effect of integrated nutrient management on growth, yield and quality of pigeonpea (Cajanus cajan L. Millsp.) C.V. PUSA.

11. Shivran, P.L., Ahlawat, I.P.S. and Shivran, D.R. 2000. Effect of phosphorus and sulphur on pigeonpea (Cajanuscajan) and succeeding wheat (Triticumaestivum) in pigeonpea-wheat cropping system. Indian Journal of Agronomy,45(1): 25-30.

12. Singh, M.K., Thakur, R., Venna, U.N., Pal, S.K. and Pasupalak, S. 1998. Productivity and nutrient balance of maize (Zea mays) + blackgram (Phaseolusmungo) intercropping as affected by fertilizer and plant density management of black gram. Indian journal of Agronomy,43(3): 495-500.

13. Tarafdar, J.C.,Raliya, R. and Rathore, I. (2012a). Microbial synthesis of phosphorus nanoparticles from Tricalcium phosphate using Aspergillustubingensis TFR-5.Journal BionanoScience, 6:84-89.

14. Tisdale, S.L., W.L. Nelson and J.D. Beaton. 1985. Soil Fertility and Fertilizers (Fourth ed.) Mac MillanPublising Company, New York.

15. Willey, R.W. 1979. Intercropping its importance and research needs. Part I. Competition and yield advantages.Field Crops Abstract, 32: 1-10.

16. Willey, R.W. and Osiru, D.S.O. 1972. Studies on mixtures of maize and beans (Phaseolus vulgaris) with particular reference to plant population.Journal Agriculture Science, Cambridge,79: 519-529.

17. Yadav, N.D. and Yadav, D.S., 1992, Production potential and economic returns of different pigeonpea (Cajanuscajan)-based cropping systems as influenced by variety and plant population. Indian journal of Agronomy,37(3)430-435. 